\title{
An Exploratory Analysis of the Market Perspective on Reclaiming Chromated Copper Arsenate (CCA) from Decommissioned Preservative-Treated Wood Utility Poles
}

\author{
Richard P. Vlosky*, Todd F. Shupe, Anand Mishra \\ Louisiana Forest Products Development Center, Louisiana State University Agricultural Center, Baton Rouge, USA \\ Email: *RVlosky@agcenter.lsu.edu
}

How to cite this paper: Vlosky, R.P., Shupe, T.F. and Mishra, A. (2016) An Exploratory Analysis of the Market Perspective on Reclaiming Chromated Copper Arsenate (CCA) from Decommissioned PreservativeTreated Wood Utility Poles. Natural Resources, 7, 544-557.

http://dx.doi.org/10.4236/nr.2016.710046

Received: June 30, 2016

Accepted: October 24, 2016

Published: October 27, 2016

Copyright $\odot 2016$ by authors and Scientific Research Publishing Inc. This work is licensed under the Creative Commons Attribution International License (CC BY 4.0).

http://creativecommons.org/licenses/by/4.0/

\section{(c) (i) Open Access}

\begin{abstract}
In the area of recycling of spent chromated copper arsenate (CCA)-treated wood, most studies to date have focused on methods of removing/extracting the residual preservative from the wood matrix. It is well recognized that exposure of CCA-treated wood to an acid solution can reverse the CCA fixation process thereby converting the CCA elements into their water-soluble form. The economic viability of the process is enhanced because it can be integrated with other technologies and products (e.g., "green" spray foam insulation, etc.). The market for the "green" CCA is the same as for traditional CCA-the wood treating industry, principally utility poles and pilings. A market research study was conducted to determine the suitability of spent CCA-treated wood as a source for recycled, "green" CCA for manufacturing "green" spray-foam insulation. Specifically, we wanted to discern the attitudes and overall perspectives of buyers/sellers (i.e., utilities and wood treating companies) of CCA preservatives and treated wood products, disposal methods and costs for decommissioned CCA-treated wood, and understand perceptions of and willingness-to-pay for "green" CCA preservatives extracted from the technologies used in this research. Results show that $60 \%$ of wood preservative treating respondents and $60 \%$ of electric utility company respondents are somewhat or greatly interested in using out-of-service utility poles as feedstock for "green insulation" as part of a new potential business venture.
\end{abstract}

\section{Keywords}

Copper Arsenate (CCA), Treated Wood, “Green” Foam Insulation, Markets, United States, Utility Companies, Wood Preservative Treaters

\section{Overview}

Preservative-treated wood plays a substantial role in the infrastructure of the nation. 
Virtually all of the preservative-treated wood that is installed is eventually decommissioned and landfilled. The goal of on-going research at Louisiana State University Agricultural Center (LSU AgCenter) is to reclaim the preservative in decommissioned preservative-treated wood and utilize the preservative-free wood as a raw material for bio-polyols which can be used to produce spray foam insulation.

In the area of recycling of spent chromated copper arsenate (CCA)-treated wood, most studies to date have focused on methods of removing/extracting the residual preservative from the wood matrix. It is well recognized that exposure of CCA-treated wood to an acid solution can reverse the CCA fixation process thereby converting the CCA elements into their water-soluble form. Thus, acid extraction using different acids and a wide range of reaction conditions has been extensively studied for removal of CCA from out-of service CCA-treated-wood.

However, acid extraction processes are slow and requires a large treating space and a large amount of acid solution. Furthermore, conventional acid extraction requires sequential extraction or a two-step extraction process to attain complete removal because none of the individual acids are able to effectively remove all three CCA elements simultaneously. Therefore, a cost effective acid extraction method is lacking.

The core innovation of the LSU technology involves the novel approach of microwave energy for binary acid solutions consisting of oxalic acid combined with either acetic or phosphoric acids. Our previous bench top research has shown that the addition of acetic acid into phosphoric acid enhanced the metal recovery rate of the mixed acid solution. This synergistic effect of mixed acetic acid and phosphoric acids is considered one of the most interesting and significant discoveries of the core invention. The minimal reaction conditions for extracting the maximum percentagee of metals were $2.75 \%$ phosphoric acid, $0.5 \%$ acetic acid, and $130^{\circ} \mathrm{C}$. The total recovery rate approached $100 \%$ for arsenic, $96.7 \%$ for chromium, and $98.6 \%$ for copper in a one step process. We can obtain virtually complete removal of all three metals at slightly more aggressive reaction conditions. The economic viability of the process is enhanced because it can be integrated with other technologies and products (e.g., "green" spray foam insulation, etc.).

\section{Explanation of Unique Aspects of the Innovation}

The research being conducted at LSU AgCenter is fundamentally unique from all other methods of CCA recycling because it involves short reaction times (i.e., 10 - $30 \mathrm{~min}$.) and provides virtually complete (over $99.9 \%$ ) recovery of all three preservative metals-copper, chromium, and arsenic. All previous studies have either required long reaction times and/or did not achieve high recovery for all three metals.

The bench top research has demonstrated that preservative-treated wood waste could be liquefied at mild temperatures into organic solvents with an acid catalyst [12] [13]. The most significant novelty was that the three metals can be removed from the liquefied wood and recycled by a simple, one-step detoxification process [9] [14]. Furthermore, the CCA-free liquefied wood has been proven to be an industrial raw material for conversion into resin adhesives [15] [16] and spray foam insulation [27], and molded 
products [17] [18]. It should be mentioned that this detoxification process accomplishes the important criteria of a closed system without discharging any by-products into the waste stream simply because even the dust collected in a dust collector can be liquefied and recycled and all chemical reagents can be recycled as well.

To improve the economic feasibility, microwave-assisted binary acid extraction of CCA from treated wood was developed. The most significant novelty herein included the discoveries of a synergistic effect of the binary acid solution of acetic and phosphoric acids and an antagonistic effect of binary acid solutions containing oxalic acid with either acetic or phosphoric acids. Results show that the microwave reactor resulted in removal of CCA in minutes in a one-step extraction process as compared to that of hours in a two-step extraction process previously reported [8]. The fast acid extraction with a microwave reactor provides enormous development potential for a continuous reactor in a commercial setting.

\section{The Product-“Green" Spray Foam Insulation}

Previous bench-top research has shown that the heavy metals can be recovered and regenerated into the proper valance state to be used as a "green" CCA preservative. It may be more profitable to separate the metals and sell them on the open metal exchange. Copper is currently selling for $\$ 2.14 \mathrm{USD} / \mathrm{lb}$. [25], Arsenic (\$0.81USD/lb.) and chromium (\$1.12USD/lb.) [11].

The recycled, metal-free wood can be used as a raw material for bio-energy applications or as an industrial raw material for conversion into resin adhesives [15] [16] and molded products [17]-[19].

The market for the "green" CCA is the same as for traditional CCA-the wood treating industry, principally utility poles and pilings. Currently, pole treaters in North America are paying around $\$ 2.10$ per pound for $60 \%$ concentrate (oxide basis) which equates to $\$ 19.40$ per gallon. There is a significant opportunity to capture a portion of this market.

A promising product is metal-free wood is for "green" spray-foam insulation. Spray-foam is a type of insulation for residential and commercial housing. Spray-foam is a substitute for traditional fiberglass insulation. The chemical agent is stored in canisters and sprayed with a special application device; it then expands and dries, forming a barrier. The advantage of foam insulation is that it expands and leaves no gaps as is the case with typical fiberglass insulation. Therefore, there are no pathways for air to escape, establishing an efficient vapor barrier. The foam also prevents the build-up of moisture, lowers the incidence of mildew and mold, and makes it more difficult for insects and other pests to burrow into a building. Spray-foam insulation is recognized as an important part of the wall component in "green" buildings, and also is one of the fastest growing areas in building products.

The development of "green" spray-foam insulation from liquefied wood could enhance the economic viability of this class of products. In addition, biomass-based spray-foam has much better biodegradability characteristics compared to petro-based foam insulation, which will benefit the environment when landfilled. 
In this paper, we focus on US market potential from the perspective of the willingness to provide (wood preservative companies) and use (electric utility companies) "green" spray-foam insulation manufactured from out-of-commission CCA-treated wood products.

\section{Potential Markets and Customers}

\subsection{Wood Preservation Industry}

The wood-preservation industry is a $\$ 4.5$ billion industry in the US [26]. For all species, a total of 8.2 billion board feet of lumber and 59.4 million cubic feet of roundwood are estimated to have been treated with waterborne preservatives in 2007 [26]. Southern pine is the dominant species for treated wood products with nearly half of all southern pine lumber being treated.

The principal customers of "green" spray-foam insulation from liquefied wood would be the existing wood preservative treating industry and the wood preservative manufacturers. Currently in the US, three chemical companies supply CCA for pressure treating wood. Today, there are 158 domestic and 27 Canadian wood treaters treating with CCA. CCA treaters are producing mainly utility poles and pilings and other minor products. In the US, roughly 4.2 million poles are produced in North America and 166 million poles are in service in the US; roughly $35 \%$ of them pressure treated with CCA [7]. The CCA annual volume produced domestically for the past five years in the North America is approximately 40 million oxide pounds.

Traditionally, CCA-treated wood has been primarily disposed within construction and demolition (C \& D) debris landfills as non-hazardous waste. It has been reported that the quantity of heavy metals leached from CCA-treated wood waste can exceed the toxicity guidelines generally used for hazardous waste identification [23]. The increasing public concern of soil and groundwater contamination at the disposal site and corresponding risk to human health and the environment has resulted in the classification of decommissioned treated wood as hazardous waste in some states and municipalities and several tort actions. Current tipping fees for construction and demolition landfills vary from $\$ 20$ to $\$ 60$ from state to state [21]. As one example, when treated wood is disposed as hazardous waste in Florida the average cost including local tipping fees, extra taxes, etc. is approximately $\$ 300$ per ton [6].

\subsection{The Electric Utility Industry}

According to the US Energy Information Administration [5], the US produces 4.06 billion GWh of electricity annually, which is $20 \%$ of the total world output. The EIA predicts that electricity demand in the US will increase by $29 \%$ from 2012 to 2040 . Since 1997 , roughly $\$ 107$ billion has been spent on new transmission infrastructure and $\$ 318$ billion on new distribution infrastructure, both in 2013 dollars. Keeping up with the additional demand for electricity will require significant investment in transmission and distribution (T \& D) infrastructure. Growth in investment in T \& D infrastructure is being driven by, apart from growth in demand for electricity, factors such as: (i) dec- 
ades of under-investment in and aging of the T \& D infrastructure (ii) targeted government initiatives and stimulus to improve the $\mathrm{T} \& \mathrm{D}$ infrastructure (iii) new renewable power generation sources that require T \& D investment (iv) shift from coal to natural gas (v) proliferation of North American oil and gas production [2] [24].

While the transmission system delivers high-voltage electricity from generators, the distribution system reduces the voltage and then delivers the electricity to retail customers. The distribution system includes miles of wires strung on various types of poles and related support systems on the retail side of electricity delivery. The demand for electric transmission and distribution ( $\mathrm{T} \& \mathrm{D}$ ) equipment in the US is forecast to rise to $\$ 30.4$ billion in 2017. It is estimated that $6 \%$ of the total invest in $\mathrm{T} \& \mathrm{D}$ will be in poles and line hardware [20].

According to industry professionals, a reasonable breakdown of cost-structure for a typical line project would be: engineering (8\%); right of way preparation $(25 \%)$; structure costs $(15 \%)$; hardware (7\%); wire and insulators (25\%); and construction with foundations (20\%). The pole selection is not the most important parameter in the decision making, because even a $25 \%$ increase in structure cost translates to less than a $4 \%$ increase in overall project cost. The utilities, while deciding upon the type of materiel used for the poles, consider various trade-offs among wood, steel, concrete, fiberglassreinforced plastic and hybrid. The criteria used for selection of types of materiel are: For wood-cost, availability, and workability; for steel-service life, known strength, engineered product; for fiber glass-service life, lightweight; for spun concrete-service life, durability [22].

Most of high-voltage (230 kilovolts or greater) transmission lines are on steel lattice towers, especially on longer spans of transmission lines; however wood poles continue to comprise majority of poles supporting smaller-span lower voltage lines. An estimated number of 120 - 200 million preservative-treated wood utility poles are currently in service in the US T \& D infrastructure [3]. It was estimated by Mankowski et al. [10] that replacement rates of wood poles ranges between $0.5 \%$ and $0.7 \%$ per year.

Common preservatives used in wood utility pole treatment include chromated copper arsenate (CCA), creosote, and pentachlorophenol (penta). Treated wood poles are starting to face the same environmental scrutiny other hazardous materials have faced for years. However, the cost advantage of wood over other materials, and favorable life cycle assessment, should keep treated wood poles in a favorable position. The increased cost of steel and other raw materials has further improved the cost advantage of the wood over other materials.

\section{The Study}

The overarching objective of this market research was to determine the suitability of spent CCA-treated wood as a source for recycled, "green" CCA for manufacturing "green" spray-foam insulation. Specifically, we wanted to discern the attitudes and overall perspectives of buyers/sellers (i.e., utilities and wood treating companies) of CCA preservatives and treated wood products, disposal methods and costs for decommissioned 
CCA-treated wood, and understand perceptions of and willingness-to-pay for "green" CCA preservatives extracted from the technologies used in this research.

\section{Methodology}

The sample frames for the study were: (1) A census of the all wood preservative treating facilities in the US and (2) A census of all electricity utility providers in the US. Market research was conducted using mailed surveys. In general, sampling, survey procedures, follow-up efforts and data analysis will be conducted in accordance with well-documented and verified techniques [4].

Mail questionnaires were chosen as the most cost effective method of data collection. The method affords a high degree of anonymity and is less limited by rigid time constraints that can impede the effectiveness of other survey methods. The questionnaires consisted of fixed response questions, including fixed alternative and multi-choice questions for responding firm demographic profiles as well as open-ended questions which will allow respondents to express thoughts and ideas not covered in the fixed format questions regarding employee-training issues. Mail survey procedures included a pre-notification letter, a cover letter accompanying the initial questionnaire, a follow-up postcard, a second follow-up letter and a second copy of the questionnaire. The source of sample frame information was US census data. The sample set was purchased from Best Lists, a national survey list company.

\section{Results}

\subsection{Wood Utility Pole Treaters}

Of the 443 mailed surveys, 67 were unusable or undeliverable, and 110 were useable for an adjusted response rate of 29\%. Figure 1 shows the geographic locations for respondent headquarters for ALL respondents while Figure 2 shows geographic locations for

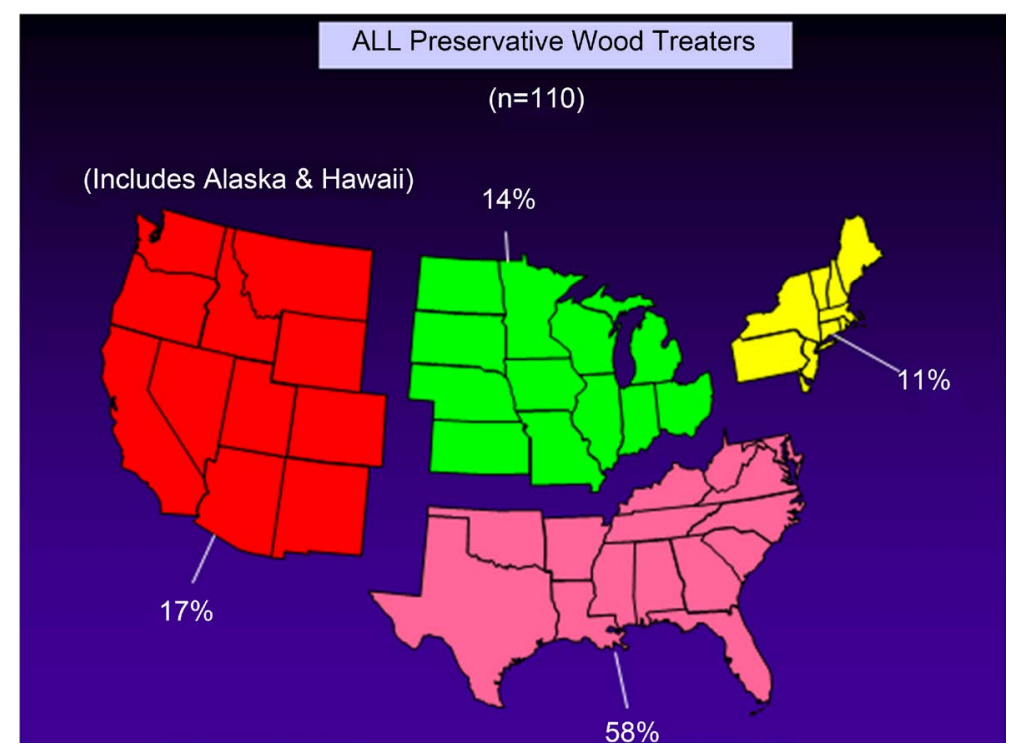

Figure 1. Geographic locations-respondent headquarters for ALL respondents. 


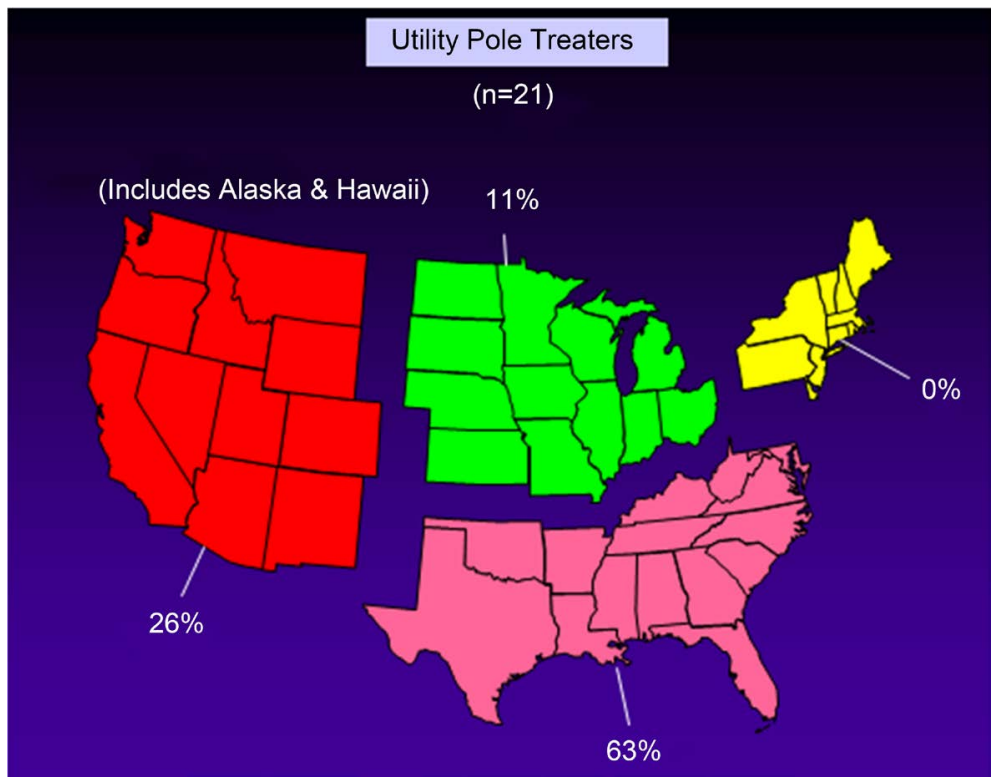

Figure 2. Geographic locations-respondent headquarters for wood utility pole treaters.

the $20 \%$ of respondents that treated utility poles.

On average for respondents, 48,260 wood utility poles are put into service annually (Table 1). The total for all respondents is just over 1 million poles. Regarding preservative treatments used for the poles respondents treat, compared to US figures, CCA accounted for $45 \%$ for both the US and study respondents, while pentachlorophenol accounted for $31 \%$ of preservatives used by respondents relative to $42 \%$ for the US. Finally, creosote accounted for $19 \%$ of respondent preservatives compared to $13 \%$ for the US (Table 2).

Respondents indicated that $85 \%$ of their production of treated utility poles were sold directly to customers (utility companies) awhile 15\% were sold to distribution interme diaries. Sixty-five percent of respondents said they knew how out-of-service wood utility poles were disposed of by their customers with "being landfilled" and "given away" ranked number 1 and 2. A distant $3^{\text {rd }}$ was: burning".

As seen in Figure 3, 50\% of respondents indicated somewhat of an interest in using out-of-service utility poles as feedstock for "green insulation" as part of a new potential business venture. Ten percent of respondents said they were very interested in such an arrangement.

Finally, wood utility pole treaters interested in potentially pursuing "green" poles for insulation were asked about their level of inclination for different approaches. Table 3 indicates that $70 \%$ of respondents were either somewhat inclined $(35 \%)$ or very inclined (35\%) to partner with a company that manufactured "green" foam insulation (at a profit, of course).

\subsection{The Electric Utility Industry}

Of the 883 mailed surveys, 144 were unusable or undeliverable, and 80 were useable for 
Table 1. Number of wood poles put into service annually $(\mathrm{n}=21)$.

\begin{tabular}{cc}
\hline Minimum & 100 \\
\hline Maximum & 150,000 \\
Mean & 48,260 \\
Total (Respondents) & $1,013,460$ \\
\hline
\end{tabular}

Table 2. Percent of preservative types used by respondents compared to US figures (percent of treatment used) $(\mathrm{n}=21)$.

\begin{tabular}{ccc}
\hline & US* & Study \\
\hline CCA & $45 \%$ & $45 \%$ \\
Pentachlorophenol & $42 \%$ & $31 \%$ \\
Creosote & $13 \%$ & $19 \%$ \\
Copper Naphthenate & $-\cdots-$ & $5 \%$ \\
\hline
\end{tabular}

${ }^{*}$ Average of beyond pesticides [1] and Vlosky [26].

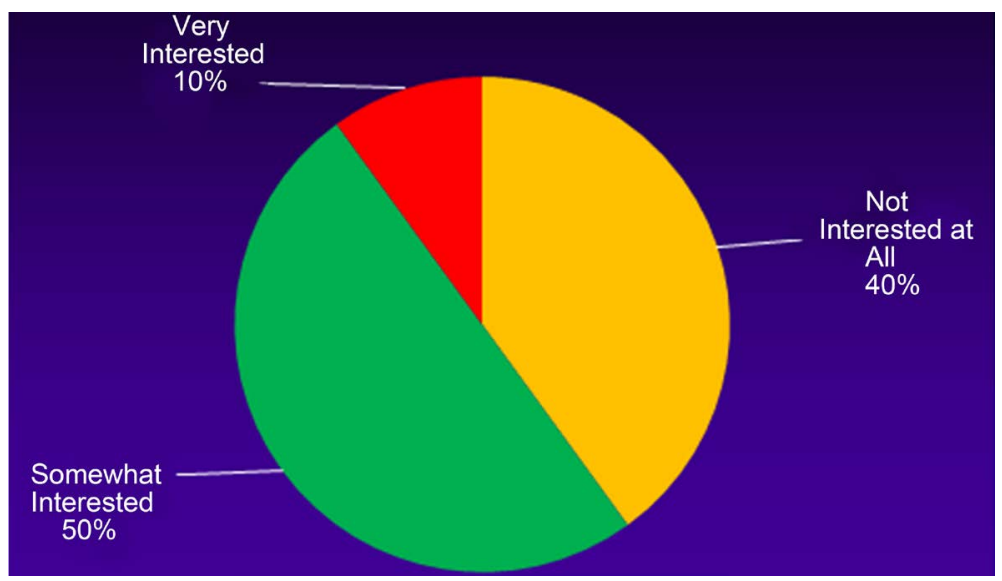

Figure 3. Interest in using out-of-service utility poles as feedstock for "green insulation" as part of a new potential business venture. (percent of respondents) $(n=21)$.

Table 3. Level of inclination of options to participate in a "Green" foam insulation business venture $(\mathrm{n}=12)$.

\begin{tabular}{cccc}
\hline & $\begin{array}{c}\text { Not Inclined } \\
\text { At All }\end{array}$ & $\begin{array}{c}\text { Somewhat } \\
\text { Inclined }\end{array}$ & $\begin{array}{c}\text { Very } \\
\text { Inclined }\end{array}$ \\
\hline $\begin{array}{c}\text { Give them away free of charge if a } \\
\text { second-party hauled them away }\end{array}$ & $65 \%$ & $35 \%$ & $10 \%$ \\
$\begin{array}{c}\text { Charge a fee that equals your current } \\
\text { cost of removal and disposal }\end{array}$ & $20 \%$ & $30 \%$ & $50 \%$ \\
$\begin{array}{c}\text { If profitable, partner with a company } \\
\text { that manufactured "green" spray } \\
\text { insulation foam }\end{array}$ & $30 \%$ & $35 \%$ & $35 \%$ \\
\hline
\end{tabular}

an adjusted response rate of $12 \%$. Figure 4 shows the geographic locations for respondent headquarters.

As seen in Figure 5, 74\% of respondent companies/co-ops have annual revenue of less than $\$ 49$ million. Figure 6 indicates that together steel and concrete utility pole 


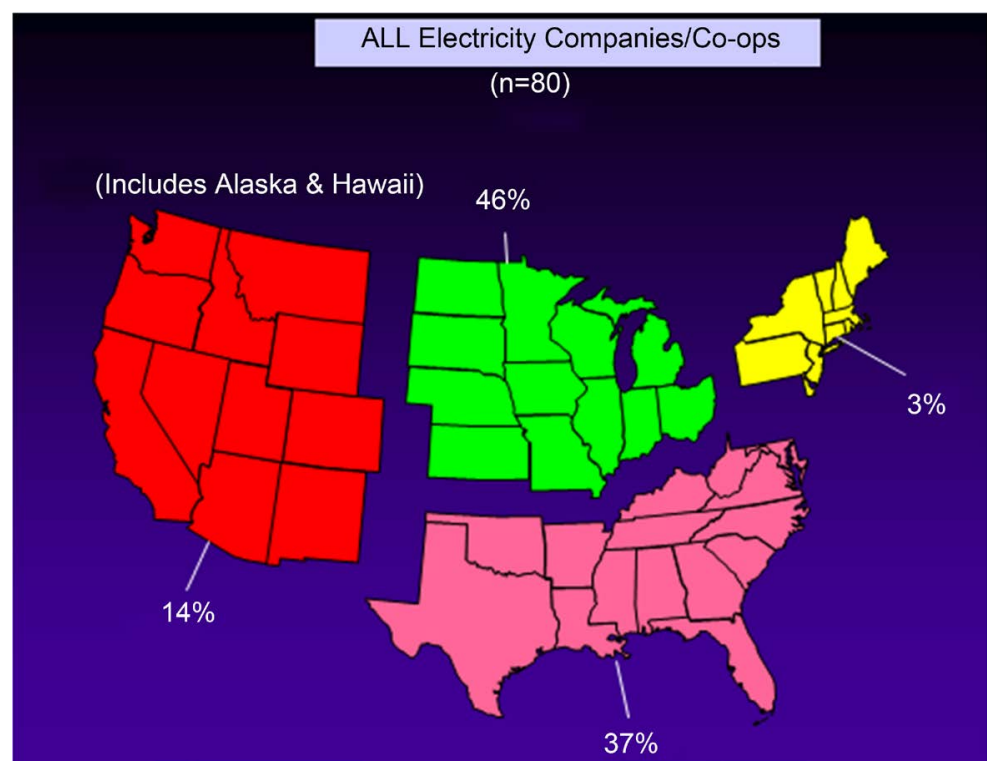

Figure 4. Geographic locations-respondent headquarters.

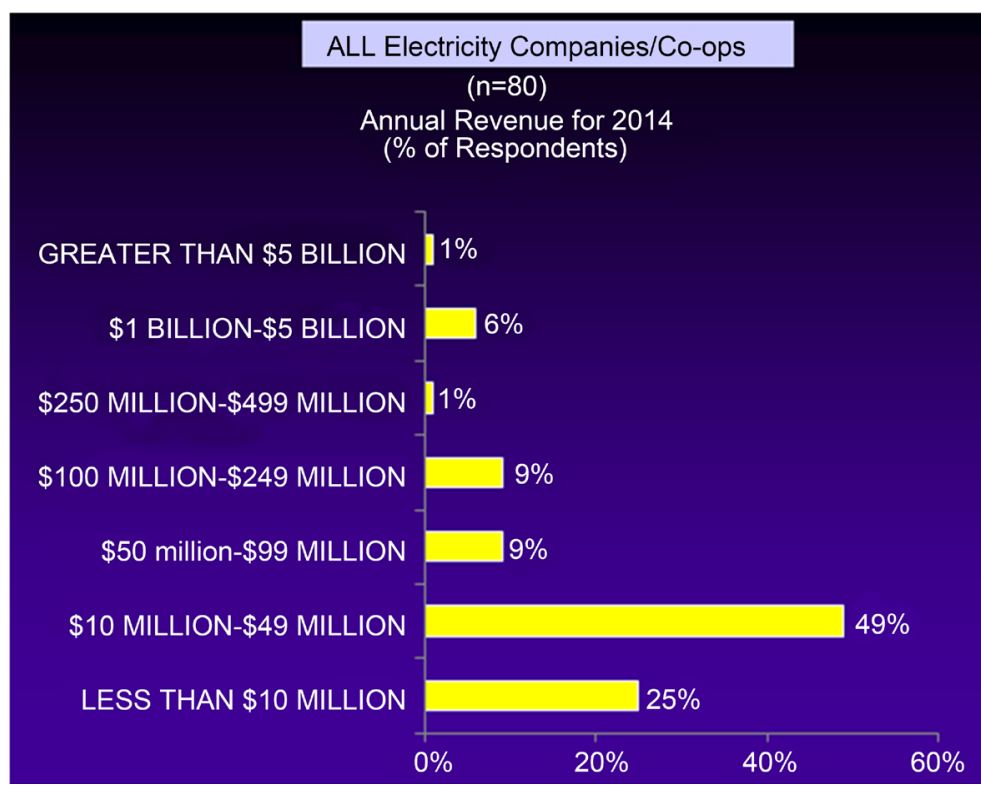

Figure 5. Respondent company size by revenue in 2014 .

constitute $40 \%$ of the total number of utility poles used among the respondents, however, wood utility poles is by far the dominant individual category.

Table 4 shows that the respondents of this study use significantly smaller proportion wood poles treated with CCA compared with the proportion for the US. On average for respondents, 117,223 wood utility poles are put in service annually (Table 5). The total for all respondents is just nearly 5.3 million poles with about $1.3 \%(69,075)$ decommissioned annually (Table 6).

Figure 7 indicates that $63 \%$ of respondents simply give away the decommissioned wood poles and $33 \%$ of respondents use them as landfill. The mean annual cost, as 


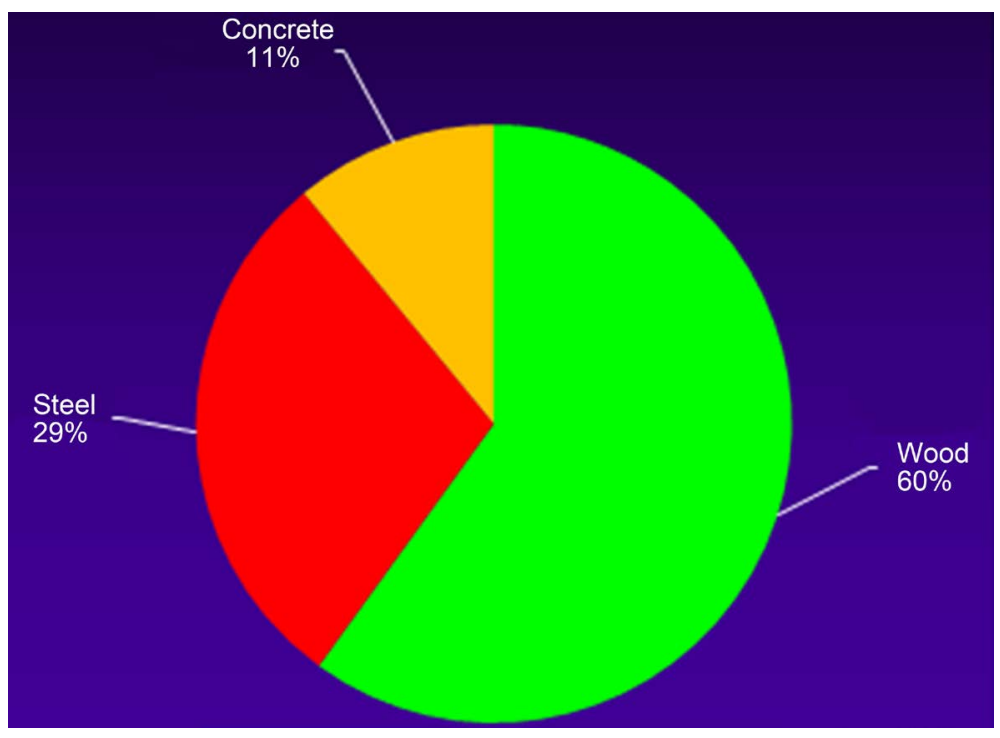

Figure 6. Percent of utility pole type used by respondents $(n=75)$.

Table 4. Percent of preservative types used by respondents compared to US figures (percent of treatment used) $(\mathrm{n}=45)$.

\begin{tabular}{ccc}
\hline & US* & Study \\
\hline CCA & $45 \%$ & $29 \%$ \\
Pentachlorophenol & $42 \%$ & $44 \%$ \\
Creosote & $13 \%$ & $19 \%$ \\
Copper Naphthenate & ----- & $4 \%$ \\
Borates & ----- & $3 \%$ \\
Copper Oxide & ----- & $1 \%$ \\
\hline
\end{tabular}

${ }^{\star}$ Average of beyond pesticides [1] and Vlosky [26].

Table 5. Number of WOOD poles currently in service $(n=45)$.

\begin{tabular}{cc}
\hline Minimum & 228 \\
\hline Maximum & $3,000,000$ \\
Mean & 117,223 \\
Total (Respondents) & $5,275,035$ \\
\hline
\end{tabular}

Table 6. Number of WOOD poles decommissioned annually $(\mathrm{n}=45)$.

\begin{tabular}{cc}
\hline Minimum & 6 \\
\hline Maximum & 60,000 \\
Mean & 1535 \\
Total (Respondents) & 69,075 \\
\hline
\end{tabular}

shown in Table 7, incurred by the respondents for decommissioning the wood utility poles is $\$ 18,220$ totaling nearly $\$ 820,000$ for all respondents.

As seen in Figure 8, 57\% of respondents are somewhat interested in new venture that could use out-of-service utility poles as feedstock for "green insulation". Similarly, 58\% 
of respondents indicated their openness for partnering with "green" spray insulation foam manufacturers (Table 8). Also, 57\% of the respondents indicated strong inclination for giving away out-of-service wood poles free of charge if second-party "green" foam venture simply hauled them away. Curiously, $51 \%$ of respondents show disinclination for charging a fee from second-party "green" foam venture in order to recoup the cost incurred in removal and disposal of wood utility poles.

\section{Conclusions}

The wood preservation industry has changed its preservation formulations in treating wood applications such as utility poles, railroad ties, marine pilings etc. A very

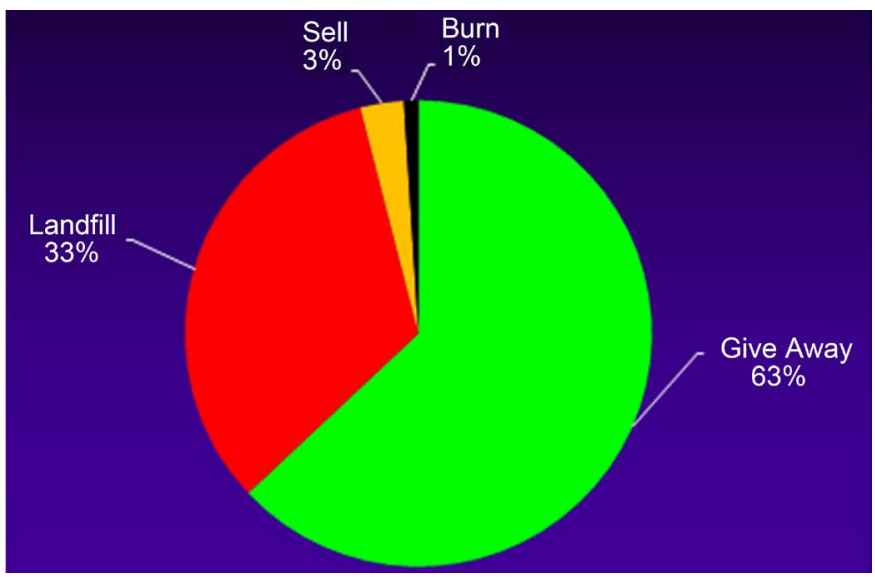

Figure 7. How decommissioned WOOD utility poles are disposed $(\mathrm{n}=45)$.

Table 7. Annual costs to decommission WOOD utility poles $(n=45)$.

\begin{tabular}{cc}
\hline Minimum & $\$ 500$ \\
\hline Maximum & $\$ 600,000$ \\
Mean & $\$ 18,220$ \\
Total (Respondents) & $\$ 819,900$
\end{tabular}

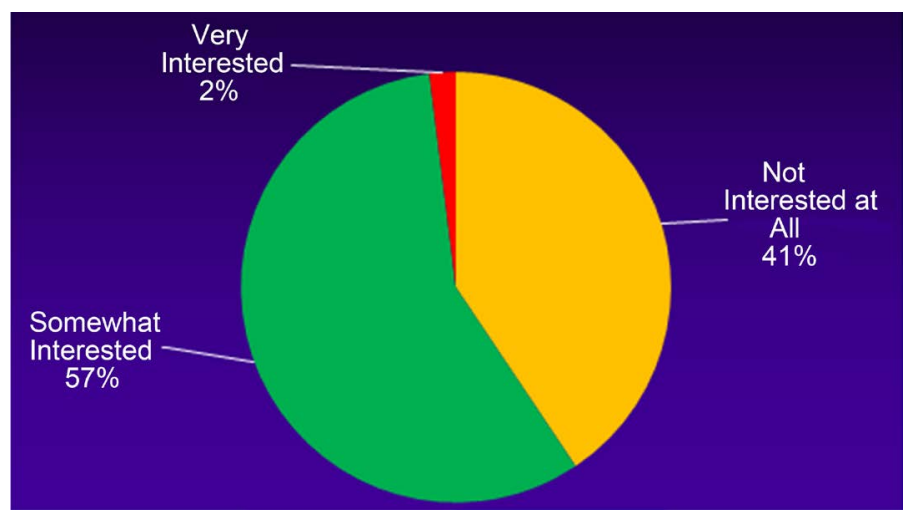

Figure 8. Interest in using out-of-service utility poles as feedstock for "green insulation" as part of a new potential business venture. (percent of respondents) $(n=45)$. 
Table 8. Level of inclination of options to participate in a "Green" foam insulation business venture $(\mathrm{n}=45)$.

\begin{tabular}{cccc}
\hline & $\begin{array}{c}\text { Not Inclined } \\
\text { At All }\end{array}$ & $\begin{array}{c}\text { Somewhat } \\
\text { Inclined }\end{array}$ & $\begin{array}{c}\text { Very } \\
\text { Inclined }\end{array}$ \\
\hline $\begin{array}{c}\text { Give them away free of charge if a } \\
\text { second-party hauled them away } \\
\begin{array}{c}\text { Charge a fee that equals your current } \\
\text { cost of removal and disposal }\end{array}\end{array}$ & $16 \%$ & $29 \%$ & $57 \%$ \\
$\begin{array}{c}\text { If profitable, partner with a company } \\
\text { that manufactured "green" spray } \\
\text { insulation foam }\end{array}$ & $51 \%$ & $32 \%$ & $17 \%$ \\
\hline
\end{tabular}

important driver for the change has been environmental and health concerns due to the nature of the chemicals in preservation formulations. Considering the number of wood poles currently in use in the US is in the range of 120 - 200 million, and also that nearly $1 \%$ of these poles are decommissioned every year, "green" spray foam insulation can play an important role to address the environmental and health concerns of the industry and society.

This study indicated that there is significant interest by respondents in the treating and utility sectors to explore the possible conversion of decommissioned CCA-treated wood into "green" spray foam insulation. Although the use of CCA has reduced, $45 \%$ of the wood-treater respondents in this study continue to use CCA, and nearly $18 \%$ of the wood poles used by electric utilities are CCA treated. An overwhelming number of respondents (99\%) indicated that decommissioned wood poles are either landfilled or simply given away.

The development of an environmentally friendly and cost effective recycling technology for spent CCA-treated wood is of great importance to the environment, the wood preservative treated industry, and the end-user of the CCA-treated wood products. All members of the supply chain for utility poles and pilings will have a vested interest in an environmentally friendly and cost effective means of disposal. This presents an opportunity for new ventures that can generate "green" CCA preservative and "green" spray foam insulation from this new renewable feedstock.

\section{References}

[1] Beyond Pesticides (2015). http://www.beyondpesticides.org/

[2] Black \& Veach Company (2014) 2014 Natural Gas Report. http://bv.com/reports/2014/natural-gas

[3] Bolin, C.A. and Smith, S. (2011) Life Cycle Assessment of ACQ-Treated Lumber with Comparison to Wood Plastic Composite Decking. Journal of Cleaner Production, 19, 620-629. http://dx.doi.org/10.1016/j.jclepro.2010.12.004

[4] Dillman, D.A. (2000) The Tailored Design Method. John Wiley \& Sons, Inc., New York.

[5] EIA (2015) Annual Energy Outlook 2015 with Projections to 2040. http://www.eia.gov/forecasts/aeo/pdf/0383(2015).pdf

[6] Florida Department of Environmental Protection (FDEP) (2013) Guidance for the Management and Disposal of CCA-Treated Wood. www.dep.state.fl.us 
[7] Freeman, M. (2014) Personal Communication with T. Shupe.

[8] Li, G.Y., Hse, C.Y. and Qin, T.F. (2012) Preparation and Characterization of Novolac Phenol Formaldehyde Resin from Liquefied Brown-Rotted Wood. Journal of Applied Polymer Science, 125, 3142-3147. http://dx.doi.org/10.1002/app.36476

[9] Lin, L.Z. and Hse, C.Y. (2002) Removal of CCA from Spent CCA-Treated Wood. Doc. No. IRG/WP 02-50192. 15 p. Proc. International Research Group on Wood Preservation, Stockholm.

[10] Mankowski, M., Hansen, E. and Morrell, J.J. (2002) Wood Pole Purchasing, Inspection, and Maintenance: A Survey of Utility Practices. Forest Products Journal, 52, 43-50.

[11] Metal-Pages.com (2016). http://www.metal-pages.com/metals/chromium/metal-prices-news-information/

[12] Pan, H., Shupe, T.F. and Hse, C.Y. (2007) Characterization of Liquefied Wood Residues from Different Liquefaction Conditions. Journal of Applied Polymer Science, 105, 37393746. http://dx.doi.org/10.1002/app.26435

[13] Pan, H., Hse, C.Y. and Shupe, T.F. (2009) Comparative Study on Liquefaction of Creosote and Chromated Copper Arsenate (CCA)-Treated Wood and Untreated Southern Pine Wood: Effects of Acid Catalyst Content, Liquefaction Time, Temperature, and Phenol to Wood Ratio. In: Hse, C.Y., Jiang, J.H. and Kuo, M.L., Eds., Proc. Advanced Biomass Science and Technology for Bio-Based Products, Chinese Academy of Forestry Pub., Beijing, 102-109.

[14] Pan, H., Hse, C.Y., Gambrell, R. and Shupe, T.F. (2009) Fractionation of Heavy Metals in Liquefied Chromated Copper Arsenate (CCA)-Treated Wood Sludge Using a Modified BCR-Sequential Extraction Procedure. Chemosphere, 77, 201-206. http://dx.doi.org/10.1016/j.chemosphere.2009.07.037

[15] Pan, H., Shupe, T.F. and Hse, C.Y. (2008) Synthesis and Cure Kinetics of Liquefied Wood/Phenol /Formaldehyde (LWPF) Resins. Journal of Applied Polymer Science, 108, 1837-1844. http://dx.doi.org/10.1002/app.27756

[16] Pan, H., Shupe, T.F. and Hse, C.Y. (2009) Characterization of Novolac Type Liquefied Wood/Phenol/Formaldehyde (LWPF) Resin. European Journal of Wood and Wood Products, 67, 427-443. http://dx.doi.org/10.1007/s00107-009-0337-x

[17] Pan, H., Shupe, T.F. and Hse, C.Y. (2006) Preliminary Investigation of Bio-Composites Fabricated from Liquefied Wood/Phenol/Formaldehyde Co-Condensation Resin. In: Frihart, C., Ed., Proceedings. Wood Adhesives 2005, San Diego, 2-4 November 2005, 257-262.

[18] Pan, H., Shupe, T.F. and Hse, C.Y. (2009) Wood Liquefaction and Its Application to Novolac Resin. In: Hse, C.Y., Jiang, J.H. and Kuo, M.L., Eds., Proc. Advanced Biomass Science and Technology for Bio-Based Products, Chinese Academy of Forestry Pub., Beijing, 39-50.

[19] Pan, H., Zheng, Z.F. and Hse, C.Y. (2011) Microwave-Assisted Liquefaction of Wood with Polyhydric Alcohols and Its Application in Preparation of Polyurethane (PU) Foams. European Journal of Wood and Wood Products, 70, 461-470. http://dx.doi.org/10.1007/s00107-011-0567-6

[20] Petina, D.A., Murphy M. and Gross, A.C. (2011) Electric Power Transmission and Equipment. Business Economics, 46, 249-259. http://dx.doi.org/10.1057/be.2011.22

[21] Roewer, J. (2013) Utility Solid Waste Activities Group. Washington DC, Personal Communication with T. Shupe.

[22] Stewart, A. (2003) Utilities Make Tradeoffs When Selecting Pole Types. http://tdworld.com/archive/utilities-make-tradeoffs-when-selecting-pole-types 
[23] Townsend, T., Tolaymat, T., Solo-Gabriele, H.M., Dubey, D., Stook, K. and Wadanambi, L. (2004) Leaching of CCA-Treated Wood: Implications for Waste Disposal. Journal of Hazardous Materials, 114, 75-91. http://dx.doi.org/10.1016/j.jhazmat.2004.06.025

[24] Transmission \& Distribution Infrastructure (2014). http://www.harriswilliams.com/sites/default/files/industry_reports/ep_td_white_paper_06_ 10_14_final.pdf?cm_mid=3575875\&cm_crmid=e5418e44-29ef-e211-9e7f-00505695730e\&c $\underline{\mathrm{m} \_ \text {medium}=\text { email }}$

[25] VincentMetals.com. (2016). http://www.vincentmetals.com/Daily_Copper_Prices.html

[26] Vlosky, R.P. (2009) Statistical Overview of the U.S. Wood Preserving Industry: 2007. Southern Forest Products Association. Kenner, LA, 34 p.

[27] Xie, J., Qi, J. Hse, C.Y. and Shupe, T.F. (2013) Effect of Lignin Derivatives in the Bio-Polyols from Microwave Liquefied Bamboo on the Properties of Polyurethane Foams. BioResources, 9, 578-588. http://dx.doi.org/10.15376/biores.9.1.578-588

\section{Submit or recommend next manuscript to SCIRP and we will provide best service} for you:

Accepting pre-submission inquiries through Email, Facebook, LinkedIn, Twitter, etc. A wide selection of journals (inclusive of 9 subjects, more than 200 journals)

Providing 24-hour high-quality service

User-friendly online submission system

Fair and swift peer-review system

Efficient typesetting and proofreading procedure

Display of the result of downloads and visits, as well as the number of cited articles Maximum dissemination of your research work

Submit your manuscript at: http://papersubmission.scirp.org/

Or contact nr@scirp.org 